\title{
Insecticidal Activities of Chromolaena odorata and Vernonia amygdalina leaf extracts against Anopheles gambiae [Diptera: Culicidae] \\ Kayode David Ileke ${ }^{1^{*}}$ and Isaac Omotayo Olabimi ${ }^{2}$
}

${ }^{1}$ Applied Entomology Unit, Department of Biology, School of Science, Federal University of Technology, Nigeria

${ }^{2}$ Enviromental Biology and Public Health Unit, Department of Biology, School of Science, Federal University of Technology, Nigeria

*Corresponding author: Kayode David Ileke, Applied Entomology Unit, Department of Biology, School of Science, Federal University of Technology, P. M. B. 704, Akure, Ondo State, Nigeria, Tel: +2348034318706

\begin{abstract}
Female Anopheles mosquitoes are the vectors of human malaria. The use of chemical insecticides for vector control has hampered with environmental pollution and insect. This suggests the need for the development of more potent and environment-friendly insecticides for effective control of malaria.This research investigated the larvicidal, pupicidal and adulticidal activities of Chromolaena odorata and Vernonia amygdalina leaf extracts against, An. gambiae in the laboratory at ambient temperature of $28 \pm 2{ }^{\circ} \mathrm{C}$ and $75 \pm 5 \%$ relative humidity. Different concentrations of 20 $\mathrm{mg} / \mathrm{L}, 40 \mathrm{mg} / \mathrm{L}, 80 \mathrm{mg} / \mathrm{L}, 120 \mathrm{mg} / \mathrm{L}$ and $160 \mathrm{mg} / \mathrm{L}$ were prepared and these aqueous solutions were used for the experiments. Larval, pupal and adult mortality of $A n$. gambiae were tested after 24 hours of exposure. Results showed that there were significant differences $(P<0.05)$ in toxicity level of the two plant extracts on An. gambiae larvae, pupae and adults. Vernonia amygdalina extract was the most toxic to $A n$. gambiae larvae at all tested concentrations of $20 \mathrm{mg} / \mathrm{L}, 40 \mathrm{mg} / \mathrm{L}, 80 \mathrm{mg} / \mathrm{L}, 120 \mathrm{mg} / \mathrm{L}$ and $160 \mathrm{mg} / \mathrm{L}$ causing $47.5 \%, 82.5 \%, 100 \%, 100 \%$ and $100 \%$ mortality after 24 hours of treatment, respectively. Chromolaena odorata extract caused $32.5 \%, 60 \%, 82.5 \%$, $92.5 \%$ and $100 \%$ mortality of An. gambiae larvae after 24 hours of treatment at concentrations $20 \mathrm{mg} / \mathrm{L}, 40 \mathrm{mg} / \mathrm{L}$, $80 \mathrm{mg} / \mathrm{L}, 120 \mathrm{mg} / \mathrm{L}$ and $160 \mathrm{mg} / \mathrm{L}$, respectively. Vernonia amygdalina extract was the most lethal to An. gambiae pupae and adults which caused $55 \%$ mortality of adult $A n$. gambiae at concentration $160 \mathrm{ml} / \mathrm{L}$. The concentration of C. odorata and V. amygdalina leaves extracts required to evoke $50 \%$ death of An. gambiae adult were $296.20 \mathrm{mg} / \mathrm{L}$ and $147.98 \mathrm{mg} / \mathrm{L}$ respectively. The $\mathrm{LC}_{90}$ of $C$. odorata extract was $3107.55 \mathrm{mg} / \mathrm{L}$ while $V$. amygdalina extract was 2221.05 $\mathrm{mg} / \mathrm{L}$ for mosquito adults. The plant extracts were not as
\end{abstract}

effective against adults compared to larva and pupa of An. gambiae. This study showed that $C$. odorata and $V$. amygdalina were toxic to malaria vector with $V$. amygdalina being more potent. This suggest that $V$. amygdalina extracts could serve as an alternative method to synthetic chemical control of malaria vectors.

\section{Keywords}

Insecticidal activities, Anopheles, Chromolaena odorata, Vernonia amygdalina, Malaria

\section{Introduction}

Several diseases are transmitted by arthropod vectors [1] of which mosquito is one of them. Mosquitoes are responsible for the transmission of diseases such as malaria, lymphatic filariasis, and dengue fever among others [2] most especially in the tropical regions of the world. Out of these diseases transmitted by mosquitoes, malaria is the most devastating in terms of the number of incidence, prevalence, morbidity and mortality [2]. It is transmitted by the mosquitoes of the genus Anopheles and it is caused by the protozoa of the Plasmodium genus [3]. Examples of Anopheles species include Anopheles gambiae, Anopheles culicifacies, Anopheles stephensi, Anopheles fluviatilis, Anopheles minimus, Anopheles dirus and Anopheles sundaicus among others with Anopheles gambiae being the prominent one among them all [4,5]. Five species of Plasmodium namely Plasmodium falciparum, Plasmodium vivax, Plasmodium malariae, Plasmodium ovale and Plasmodium 
knowlesi are responsible for human malaria [6] but $P$. falciparum and $P$. vivax are most notorious in terms of the number of cases they are responsible for [3].

They were an estimated 219 million cases of malaria with 435,000 of them resulting in death in 2017 [3]. In order to stop or reduce the transmission of malaria parasites, there is need to control the vector population. Several methods such as habitat modification [7], the use of synthetic chemical insecticides [4] and the use of biological means such as employing natural predators, parasites and parasitoids to control the populations of mosquitoes $[8,9]$. The major method that have been employed in the control of mosquitoes is the use of synthethic insecticides such as chlorodane, aldrin, Dieldrin, dichlorodiphenyl trichoroethane (DDT) among others [4].

However, these chemical have been shown to have negative effect in the dynamics of the earth's ecosystem resulting in resistance of mosquito species to the chemicals, environmental pollution and toxicity to human and other non-targeted organisms [10]. Hence, there have been clamor by various quarters to develop a safe means to combat the proliferation of insect vector species [11]. This has led to the focus on developing insecticides from botanical sources that are safe to use in the environment due to the fact that they are easily degradable and less toxic to humans and non-targeted organisms $[12,13]$.

Several plant materials such as Alstonia boonei, Curuma longa, Cymbopogon winterianus, Ocimum americanum, Nepeta cataria, Viola odorata, Melaleuca quinquenervia, Azadirachta indica, Citrus medica, Nicotiana tabacum, Anacardium occidentale, Aframomum melegueta, Garcinia kola, Citrus sinensis and Murraya koenigii have been used to control mosquitoes [14-22].

Chromolaena odorata is a fast-growing perennial herb which belongs to the family Asteraceae [23]. The plants are known for its medicinal value in many areas as well as pests control purposes [23]. Chromolaena odorata contains carcinogenic pyrrolizidine alkaloids [24]. It is not habitat specific and nature of soil, it grows generally in the wild (abandoned land) [25]. The plantis acknowledged for its high proliferation and one of the world worst tropical weeds [26].

Vernonia amygdalina belong to the family Asteraceae and grows in the tropical regions of Africa [23]. The plant is a shrub, evergreen in colour and can grow between 2-5 $\mathrm{m}$ in height with petiolate leaf of about $6 \mathrm{~mm}$ in diameter [27]. The plant is bitter due to the characteristic odour and bitter taste of the leaves owing to the presence of anti-nutritional factors such as alkaloids, saponins, tannins and glycosides [28,29]. The aim of this research study isto investigate the antimosquito activities of $C$. odorata and $V$. amygdalina leaf extracts on the larvae, pupae and adults of malaria vector, An. gambiae.

\section{Materials and Methods}

\section{Place and duration of study}

The research was conducted at the Storage Entomology Postgraduate Research Laboratory, Department of Biology, Federal University of Technology, Akure, Nigeria between August and November, 2018.

\section{Collection and rearing of larva, pupa and adult mosquito}

Mosquito bait was established under a partial shade in an open field by filling a white bucket with rain water. Yeast was sprinkled on the surface of the water to serves as source of foods for the nourishment of larvae. Wild mosquitoes were allowed to freely visit the baits and to lay eggs. This was monitored for 4-6 days for the development of eggs and first instar larvae. Subsequently, the larvae were harvested and taken into the laboratory for identification into species levels [30]. Anopheles gambiae larvae were transferred into another plastic container containing rain water. Some of the larvae were used for the larvicidal tests while the remaining larvae nurtured to pupae for 4-6 days for pupicidal tests. Adult mosquito that emerged from pupae cultured were fed with sucrose solution [31].

\section{Collection of plant materials}

Chromolaena odorata and $V$. amygdalina leaves that have not be sprayed with chemical insecticides (based on the information obtained from the farmer) were obtained in fresh form a farm at Ogbese, Ondo State, Nigeria. They were taken to the Biology Department, Federal University of Technology, Akure, Ondo State for authentication.

\section{Extraction of plant materials}

Chromolaena odorata and $V$. amygdalina leaves were washed separately with distilled water, shade dried, cut into small pieces and air dried for 14 days in the laboratory before pulverized into fine powders using an industrial electric pulverizing machine at the Department of Animal Production and Health Laboratory, Federal University of Technology, Akure. The powders were further sieved to pass through $\mathrm{mm}^{2}$ perforations and kept in an air-tight plastic containers for storage before use at ambient temperature (28 \pm 2$)$ ${ }^{\circ} \mathrm{C}$.

About $300 \mathrm{~g}$ of $C$. odorata and $V$. amygdalina powders were soaked separately in an extraction bottle containing $500 \mathrm{ml}$ of absolute methanol for 72 hours. The mixture was stirred occasionally with a glass rod and extraction was terminated after three days. Filtration was carried out using a double layer of Whatman No. 1 filter papers and solvent evaporated using a rotary 
evaporator at 30 to $40{ }^{\circ} \mathrm{C}$ with rotary speed of three to six rpm for eight hours [32]. The resulting extracts were air dried in order to remove traces of methanol. The extracts were kept in labeled plastic bottles till when needed.

Standard stock solutions were prepared by dissolving $3 \mathrm{~g}$ of the crude extracts in 1 Litre of water. From these stock solutions, different concentrations of $20 \mathrm{mg} / \mathrm{L}, 40$ $\mathrm{mg} / \mathrm{L}, 80 \mathrm{mg} / \mathrm{L}, 120 \mathrm{mg} / \mathrm{L}$ and $160 \mathrm{mg} / \mathrm{L}$ were prepared and these aqueous solutions were used for the various experiments.

\section{Anti-larval activity of $C$. odorata and $V$. amygdalina extracts}

Twenty (20) $3^{\text {rd }} / 4^{\text {th }}$ larval instar of An. gambiae were introduced into $C$. odorata and $V$. amygdalina extracts separately at concentrations $20 \mathrm{mg} / \mathrm{L}, 40 \mathrm{mg} / \mathrm{L}, 80 \mathrm{mg} / \mathrm{L}$, $120 \mathrm{mg} / \mathrm{L}$ and $160 \mathrm{mg} / \mathrm{L}$ with a set of control containing rain water. All tested concentrations were replicated four times. The number of dead larvae were counted and recorded accordingly after 24 hours of exposure. Dead larvae were those unable of rising to the surface or without the characteristic diving reaction when the water was disturbed [33].

$\%$ Larval Mortality $=\frac{\text { Number of dead larvae }}{\text { Number of larvae introduced }} \times \frac{100}{1}$

Percentage larvae mortality was corrected using Abbott [25] formula thus:

$$
P_{T}=\frac{P_{o}-P_{c}}{100-P_{o}} \times \frac{100}{1}
$$

Where $\mathrm{P}_{\mathrm{T}}=$ corrected mortality (\%)

$\mathrm{P}_{\mathrm{O}}=$ observed mortality (\%)

$\mathrm{P}_{\mathrm{C}}=$ control mortality $(\%)$

\section{Anti-pupal activity of $C$. odorata and $V$. amygdalina extracts}

Twenty-two days old pupae of An. gambiae were introduced into $C$. odorata and $V$. amygdalina extracts separately at concentrations $20 \mathrm{mg} / \mathrm{L}, 40 \mathrm{mg} / \mathrm{L}, 80 \mathrm{mg} / \mathrm{L}$, $120 \mathrm{mg} / \mathrm{L}$ and $160 \mathrm{mg} / \mathrm{L}$ with a set of controls containing rain water. All tested concentrations were replicated four times. The number of dead pupae were counted and recorded accordingly after 24 hours of treatment. Percentage pupal mortality were calculated using standard method and \% pupae mortality was corrected using Abbott formula [34].

\section{Anti-adult fumigant efficacy of $C$. odorata and $V$. amygdalina extracts}

Twenty adults were introduced into a test-tube covered with cotton wool [9]. Strips of Whatman's No.1 filter papers soaked with $20 \mathrm{mg} / \mathrm{L}, 40 \mathrm{mg} / \mathrm{L}, 80 \mathrm{mg} / \mathrm{L}$, $120 \mathrm{mg} / \mathrm{L}$ and $160 \mathrm{mg} / \mathrm{L}$ of C. odorata and $\mathrm{V}$. amygdalina extracts were suspended in the test tube separately in four replicates. Mortality of adult insect was evaluated after 24 hours of treatment using standard method. Percentage adult mortality was corrected using Abbott formula as illustrated above.

\section{Statistical analysis of data}

Data were subjected to analysis of variance and means were separated using the new Duncan's multiple range test. The log-Probit model analysis was carried out on larvicidal, pupicidal and adulticidal bioassay results to assess the $50 \%$ lethal concentration $\left(\mathrm{LC}_{50}\right)$ and $90 \%$ lethal concentration $\left(\mathrm{LC}_{90}\right)$.

\section{Result}

\section{Anti-larval activity of $C$. odorata and $V$. amygdalina extracts on An. gambiae larvae}

There was a significant difference $(P<0.05)$ in toxicity level of $C$. odorata and $V$. amygdalina extracts on An. gambiae larvae at all tested concentrations (Table 1). Vernonia amygdalina extract was the most toxic to An. gambiae at all tested concentrations of 20 $\mathrm{mg} / \mathrm{L}, 40 \mathrm{mg} / \mathrm{L}, 80 \mathrm{mg} / \mathrm{L}, 120 \mathrm{mg} / \mathrm{L}$ and $160 \mathrm{mg} / \mathrm{L}$ which evoked $47.5 \%, 82.5 \%, 100 \%, 100 \%$ and $100 \%$ mortality after 24 hours of treatment, respectively. Chromolaena odorata extract caused $32.5 \%, 60 \%, 82.5 \%, 92.5 \%$ and $100 \%$ mortality of An. gambiae larvae after 24 hours of treatment at rates $20 \mathrm{mg} / \mathrm{L}, 40 \mathrm{mg} / \mathrm{L}, 80 \mathrm{mg} / \mathrm{L}, 120 \mathrm{mg} / \mathrm{L}$ and $160 \mathrm{mg} / \mathrm{L}$, respectively.

\section{Anti-pupal activity of $C$. odorata and $V$. amygdalina extracts on An. gambiae pupae}

Anti-pupal activity of $C$. odorata and $V$. amygdalina extracts on percentage mortality of An. gambiae larvae is presented in Table 2. Generally, pupae mortality occurred in a dosage-dependent manner. There

Table 1: Toxicity of C. odorata and V. amygdalina Leaves Extracts on \% mortality of An. gambiae Larvae after 24 hours of exposure.

\begin{tabular}{|c|c|c|c|c|c|}
\hline \multirow[t]{2}{*}{ Plant Extracts } & \multicolumn{5}{|c|}{ Concentration (mg/L) } \\
\hline & 20 & 40 & 80 & 120 & 160 \\
\hline C. odorata & $32.50 \pm 2.55^{b}$ & $60.00 \pm 2.04^{b}$ & $82.50 \pm 2.36^{b}$ & $92.50 \pm 3.55^{b}$ & $100.00 \pm 0.0^{b}$ \\
\hline V. amygdalina & $47.50 \pm 2.36^{c}$ & $82.50 \pm 3.55^{c}$ & $100.00 \pm 3.36^{c}$ & $100.00 \pm 0.00^{b}$ & $100.00 \pm 0.00^{b}$ \\
\hline Control & $0.00 \pm 0.00^{a}$ & $0.00 \pm 0.00^{a}$ & $0.00 \pm 0.00^{a}$ & $0.00 \pm 0.00^{a}$ & $0.00 \pm 0.00^{\mathrm{a}}$ \\
\hline
\end{tabular}

All values are means of four replicates followed by \pm standard error of the mean. Mean followed by the same letters, superscript at the end of each value, down the column are not significantly different $(p>0.05)$ from one another using New Duncan's Multiple Range Test. 
Table 2: Toxicity of $C$. odorata and $V$. amygdalina extracts on \% mortality of An. gambiae pupae after 24 hours of exposure.

\begin{tabular}{|l|l|l|l|l|l|}
\hline \multirow{2}{*}{ Plant Extracts } & \multicolumn{5}{l|}{ Concentration $(\mathbf{m g} / \mathbf{L})$} \\
\cline { 2 - 6 } & 20 & 40 & 80 & 120 & 160 \\
\hline C. odorata & $20.00 \pm 2.04^{\mathrm{b}}$ & $37.50 \pm 2.36^{\mathrm{b}}$ & $50.00 \pm 2.04^{\mathrm{b}}$ & $77.50 \pm 3.36^{\mathrm{b}}$ & $100.00 \pm 0.0^{\mathrm{b}}$ \\
\hline V. amygdalina & $32.50 \pm 2.55^{\mathrm{c}}$ & $50.00 \pm 2.04^{\mathrm{c}}$ & $77.50 \pm 3.36^{\mathrm{c}}$ & $100.00 \pm 0.00^{\mathrm{c}}$ & $100.00 \pm 0.00^{\mathrm{c}}$ \\
\hline Control & $0.00 \pm 0.00^{\mathrm{a}}$ & $0.00 \pm 0.00^{\mathrm{a}}$ & $0.00 \pm 0.00^{\mathrm{a}}$ & $0.00 \pm 0.00^{\mathrm{a}}$ & $0.00 \pm 0.00^{\mathrm{a}}$ \\
\hline
\end{tabular}

All values are means of four replicate followed by \pm standard error of the mean. Mean followed by the same letters, superscript at the end of each value, down the column are not significantly different $(p>0.05)$ from one another using New Duncan's Multiple Range Test.

Table 3: Fumigant toxicity of $C$. odorata and V. amygdalina on An. gambiae adults.

\begin{tabular}{|c|c|c|c|c|c|}
\hline \multirow[t]{2}{*}{ Extracts of plants } & \multicolumn{5}{|c|}{ Concentration (mg/L) } \\
\hline & 20 & 40 & 80 & 120 & 160 \\
\hline C. odorata & $7.50 \pm 0.36^{b}$ & $15.00 \pm 1.39^{b}$ & $20.00 \pm 2.04^{b}$ & $30.00 \pm 2.04^{b}$ & $40.00 \pm 2.04^{c}$ \\
\hline V. amygdalina & $17.50 \pm 1.36^{c}$ & $27.50 \pm 2.36^{c}$ & $37.50 \pm 2.36^{c}$ & $42.50 \pm 2.22^{c}$ & $55.00 \pm 2.39^{c}$ \\
\hline Untreated & $0.00 \pm 0.00^{a}$ & $0.00 \pm 0.00^{a}$ & $0.00 \pm 0.00^{a}$ & $0.00 \pm 0.00^{a}$ & $0.00 \pm 0.00^{a}$ \\
\hline
\end{tabular}

Each value is a mean \pm standard error of four replicates. Means followed by the same letter along the column are not significantly different $(p>0.05)$ using New Duncan's Multiple Range Test.

Table 4: $50 \%$ and $90 \%$ Lethal Concentration of $C$. odorata and $V$. amygdalina Leaves Extracts on An. gambiae larvae, pupae and adults.

\begin{tabular}{|l|l|l|l|}
\hline Mosquito & Plant Extracts & Concentration $(\mathbf{m g} / \mathbf{L})$ & \multicolumn{2}{l|}{ (Lower - Upper Limit) } \\
\hline & & LC $_{50}$ (Lower - Upper Limit) & $95.73(82.33-115.99)$ \\
\hline Larvae & C. odorata & $31.33(26.81-35.69)$ & $44.56(39.24-53.18)$ \\
\hline Pupae & V. amygdalina & $21.42(18.51-23.99)$ & $117.66(91.21-144.11)$ \\
\hline & C. odorata & $53.61(12.03-118.45)$ & $92.29(56.78-127.80)$ \\
\hline Adults & V. amygdalina & $33.93(11.88-54.82)$ & $3107.55(1204.61-5010.49)$ \\
\hline & C. odorata & $296.20(200.66-613.94)$ & $2221.05(912.69-3529.41)$ \\
\hline
\end{tabular}

was a significant difference $(P<0.05)$ in toxicity level of the two plant extracts on An. gambiae pupae at concentrations. Vernonia amygdalina extract was the most lethal to An. gambiae pupae which evoked 32.5\%, $50 \%, 77.5 \%, 100 \%$ and $100 \%$ mortality after 24 hours of treatment at concentrations $20 \mathrm{mg} / \mathrm{L}, 40 \mathrm{mg} / \mathrm{L}, 80 \mathrm{mg} / \mathrm{L}$, $120 \mathrm{mg} / \mathrm{L}$ and $160 \mathrm{mg} / \mathrm{L}$, respectively. Chromolaena odorata extract caused 20\%, 37.5\%, 50\%, $77.5 \%$ and $100 \%$ mortality of An. gambiae larvae after 24 hours of treatment at concentrations $20 \mathrm{mg} / \mathrm{L}, 40 \mathrm{mg} / \mathrm{L}, 80$ $\mathrm{mg} / \mathrm{L}, 120 \mathrm{mg} / \mathrm{L}$ and $160 \mathrm{mg} / \mathrm{L}$, respectively. The higher the concentration, the more the mortality rate of pupae mosquito.

\section{Anti-adult fumigant efficacy of $C$. odorata and $V$. amygdalina leaves extracts on An. gambiae adults}

Fumigant toxicity of $C$. odorata and $V$. amygdalina extracts on percentage mortality of An. gambiae adults is presented in Table 3. Adult mortality occurred in a dosage-dependent manner. There was a significant difference $(P<0.05)$ in toxicity level of the two plant extracts on An. gambiae adults at concentrations $20 \mathrm{mg} / \mathrm{L}, 40 \mathrm{mg} / \mathrm{L}, 80 \mathrm{mg} / \mathrm{L}, 120 \mathrm{mg} / \mathrm{L}$ and $160 \mathrm{mg} / \mathrm{L}$. Vernonia amygdalina caused $17.5 \%, 27.5 \%, 37.5 \%$, $42.5 \%$ and $55 \%$ mortality of adult An. gambiae after
24 hours of treatment at concentrations $20 \mathrm{mg} / \mathrm{L}, 40$ $\mathrm{mg} / \mathrm{L}, 80 \mathrm{mg} / \mathrm{L}, 120 \mathrm{mg} / \mathrm{L}$ and $160 \mathrm{mg} / \mathrm{L}$, respectively. Chromolaena odorata extract caused $7.5 \%, 15 \%, 20 \%$, $30 \%$ and $40 \%$ mortality of An. gambiae larvae after 24 hours of treatment at concentrations $20 \mathrm{mg} / \mathrm{L}, 40 \mathrm{mg} / \mathrm{L}$, $80 \mathrm{mg} / \mathrm{L}, 120 \mathrm{mg} / \mathrm{L}$ and $160 \mathrm{mg} / \mathrm{L}$, respectively. The higher the concentration, the more the mortality rate of adult An. gambiae.

\section{$\mathrm{LC}_{50}$ and $\mathrm{LC}_{90}$ values calculated for $C$. odorata and V. amygdalina leaves extracts on An. gambiae larvae, pupae and adults based on the log-probit regression analysis}

The $50 \%$ lethal concentration of $C$. odorata extract was $31.33 \mathrm{mg} / \mathrm{L}$ while $V$. amygdalina extract was 21.42 $\mathrm{mg} / \mathrm{L}$ for $A n$. gambiae larvae. The concentration of C. odorata and $V$. amygdalina leaf extracts to cause $90 \%$ death of An. gambiae larvae were $95.73 \mathrm{mg} / \mathrm{L}$ and $44.56 \mathrm{mg} / \mathrm{L}$ respectively (Table 4). Chromolaena odorata extract required more concentration than $V$. amygdalina leaf extracts to cause $50 \%$ and $90 \%$ death of An. gambiae larvae. The concentration of $C$. odorata and $V$. amygdalina leaf extracts to cause $50 \%$ death of mosquito pupae were $53.61 \mathrm{mg} / \mathrm{L}$ and $33.93 \mathrm{mg} / \mathrm{L}$ 
respectively. The concentration of $C$. odorata and $V$. amygdalina leaf extracts to cause $90 \%$ death of $A n$. gambiae pupae were $117.66 \mathrm{mg} / \mathrm{L}$ and $92.29 \mathrm{mg} / \mathrm{L}$ respectively. Vernonia amygdalina extract required less concentration than $C$. odorata leaves extracts to cause $50 \%$ and $90 \%$ death of An. gambiae pupae. The concentration of $C$. odorata and $V$. amygdalina leaves extracts required to evoke $50 \%$ death of $A n$. gambiae adult were $296.20 \mathrm{mg} / \mathrm{L}$ and $147.98 \mathrm{mg} / \mathrm{L}$ respectively. The $\mathrm{LC}_{90}$ of $C$. odorata extract was $3107.55 \mathrm{mg} / \mathrm{L}$ while V. amygdalina extract was $2221.05 \mathrm{mg} / \mathrm{L}$ for mosquito adults. The plant extracts were not as effective against adults compared to larva and pupa of An. gambiae.

\section{Discussion}

The use of plants as mosquitocides in lieu of synthetic chemical insecticides for the management of malaria vectors is gaining attention in developing nations such as Nigeria $[17,20]$. Utilization of $C$. odorata and $V$. amygdalina in the biocontrol of insect pest of cereals, legumes and vectors of malaria have been previously reported [35-42].

The result obtained in this study showed that $C$. odorata and $V$. amygdalina leaves extracts were effective in the control of larva, pupa and adult stages of An. gambiae. The larvicidal, pupicidal and adulticidal potentials of $C$. odorata and $V$. amygdalina extracts were concentration dependent. The higher the concentration, the higher the mortality rate of larva, pupa and adult mosquito. Larvae were more susceptible to $C$. odorata and $V$. amygdalina extracts than pupa and adults stages. This may be due to the swimming ability of the pupae, picking the lethal dose in the process of searching for food $[18,21,43]$. The extract also reduces dissolved oxygen which could have caused their death $[18,43]$.

Vernonia amygdalina leaf extract was the most toxic to all stages of An. Gambiaein this study. The biocontrol of $V$. amygdalina against stored product pest have been reported [35-39,42]. Adedire and Lajide [35] reported $100 \%$ mortality of maize weevil, Sitophilus zeamais when treated with $V$. amygdalina Musa, et al. [36] also reported the efficacy of $V$. amygdalina in the management of cowpea beetle, Callosobruchus maculatus. Moses and Dorathy [37] reported that bitter leaf gave the best protection against cowpea weevil when compared with garlic and ginger. Akunne, et al. [39] reported on efficacy of mixed application of leaf powders of $V$. amygdalina and Azadirachta indica against adult $C$. maculatus. lleke [42] reported on entomotoxicant potential of bitter leaf, $V$. amygdalina powder in the control of Cowpea bruchid, $C$. maculatus infesting stored cow peaseeds. The larvicidal and pupicidal bioefficacies of $V$. amygdalina extract on the malaria vector developmental stages could be linked to the presence of some chemical compounds like sesquiterpene lactones containing vernodalin, vernodalol and 11,13-dihydrovernodalin which act as insect feeding deterrent [44].

Chromolaena odorata extract also effectively control larva and pupa stages of malaria vector. This agreed with many earlier researchers on the use of botanicals against suppression of vectors malaria [38,39]. Ahiati, et al. [38] reported on the insecticidal effects of $C$. Odorata Oil extracts on the Larvae and adults of mosquitoes (Family Culicidae). Jagruti, et al. [39] reported on the larvicidal activity of methanolic leaf extracts of plant, C. odorata L. (Asteraceae) against vector mosquito. Chromolaena odorata extract had been utilized against a household pests such as cockroaches. Udebuani, et al. [41] reported on the effectiveness of $C$. odorata against adult stage of American cockroach, Periplaneta americana. Insecticidal property of $C$. odorata could be linked to it chemical constituents such as tannin, saponin, flavonoid and alkaloids. The presence of these phytochemical alters some biochemical functions of organisms. Man [45] reported that increase mortality of An. gambiae rate which was reported in thin study could be attributed to phytochemical content of the leaf extract. Studies have shown that high dose of flavonoid alters the normal body functioning of insects [46,47]. Kelm and Nair [48] also reported the presence of flavonoid, tannin, saponin in leaf extract of $C$. odorata. Saponin are a class of steroidal or triterpenoid secondary plant metabolite with diverse biological properties, such as antifeeding $[47,49]$ and growth inhibitory activities $[47,50]$. Chromolaena odorata and V. amygdalina leaves were less toxic to the adult mosquito compared with larvae and pupae of An. gambiae. The major limitation of this study is that we did not identify the active ingredients in the leaf extracts. However, we propose, in the future, to characterize active ingredients in the $C$. odorata and $V$. amygdalina leaf extracts with a view to developing a potent insecticide against all the life stages of An. gambiae.

\section{Conclusion}

Anopheles gambiae larvae were more susceptible to leaf extracts tested than their pupae and adults at all tested concentrations. In addition, V. amygdalina extracts required less concentration than $C$. odorata to cause $50 \%$ and $90 \%$ death of malaria vector, $A n$. gambiae larvae, pupae and adults. The test plants can be incorporated into a control strategy or intervention programmes on the management of malaria vector, $A n$. gambiae.

\section{Acknowledgments}

We appreciate Dr. Foluso Akindele Ologundudu, (Plant Physiologist/Taxonomist) of the Department of Biology, Federal University of Technology, Akure, Nigeria who assisted in the authentication of two plants assessed in this study. 


\section{References}

1. Leitner WW, Wali T, Kincaid R, Denis AC (2015) Arthropod Vectors and Disease Transmission : Translational Aspects. PLoS Negl Trop Dis 1-11.

2. World Health Organization (WHO) (2017) Vector-borne diseases.

3. World Health Organization (WHO) (2018) Malaria.

4. Singh RK, Kumar G, Mittal PK (2014) Insecticide Susceptibility status of malaria vectors in India: A Review. International Journal of Mosquito Research 1: 5-9.

5. World Health Organization (WHO) (2015) World Malaria Report.

6. Oddoux O, Debourgogne A, Kantele A, Kocken $\mathrm{CH}$, Jokiranta TS, et al. (2011) Identification of the five human Plasmodium species including $P$. knowlesi by real-time polymerase chain reaction. Eur $\mathrm{J}$ Clin Microbiol Infect Dis 30: $597-601$

7. Jacups S, Kurucz N, Whitters R, Whelan P (2011) Habitat modification for mosquito control in the Ilparpa Swamp, Northern Territory, Australia. J Vector Ecol 36: 292-299.

8. Kamareddine $L$ (2012) The biological control of the malaria vector. Toxins 4: 748-767.

9. Kwenti ET (2017) Biological Control of Parasites. In: Prof. HanemKhater, Natural Remedies in the Fight against Parasites, InTech, Croatia, 23-58.

10. Mahmood I, Imadi SR, Shazadi K, Gul A (2015) Effects of Pesticides on Environment. Plant, Soil and Microbes.

11. Gupta S, Dikshit AK (2010) Biopesticides: An ecofriendly approach for pest control. Journal of Biopesticides 3: 186188

12. Shaalan EAS, Canyon D, Younes MWF, Abdel-Wahab H, Mansour AH (2005) A review of botanical phytochemicals with mosquitocidal potential. Environ Int 31: 1149-1166.

13. Thomson M, Vijan A (2016) Environmental friendly biopesticides: A Review. Journal of Agriculture and Allied Sciences 5: 31-39.

14. Tawatsin A, Wratten SD, Scott RR, Thavara $U$, Techadamrongsin $Y$ (2001) Repellency of volatile oils from plants against three mosquito vectors. J Vector Ecol 26: 76-82.

15. Akinkurolere RO, Adedire CO, Odeyemi OO, Raji J, Owoeye JA (2011) Bioefficacy of extracts of some indigenous Nigerian plants on the developmental stages of mosquito (Anopheles gambiae). Jordan Journal of Biological Sciences 4: 237-242.

16. Shankar BS, Saravanan T, Ragavi M, Kaviya G, Anushree A, et al. (2013) Screening of local plants for their repellent activity against mosquitoes (Diptera: Culicidae). Journal of Mosquito Research 3: 97-104.

17. lleke KD, Afolabi OJ, Ogungbite OC, Olayinka-Olagunju JO, Akanbi OM (2014) Mosquitocidal activity of Anacardium occidentale, Afromomum melegueta, Garcina kola and Citrus sinensis against the developmental stages of mosquito, Anopheles gambiae Giles. Journal of Mosquito Research 4: 21-26.

18. lleke KD, Oyeniyi EA, Ogungbite OC, Adesina JM (2015) Nicotiana tabacum a prospective mosquitocide in the management of Anopheles gambiae(Giles). International Journal of Mosquito Research 2: 19-23.

19. lleke KD, Ogungbite OC (2015) Alstonia boonei De Wild oil extract in the management of mosquito (Anopheles gambiae), a vector of malaria disease. Journal of Coastal Life Medicine 3: 557-563.

20. Ileke KD, Adesina JM, Okunola OG (2017) Larvicidal and pupicidal potential of Afromomum melegueta K. Schum extracts against mosquito, Anopheles species. Journal of the Entomological Research Society 19: 121-127.

21. lleke KD (2018) Entomocidal Properties of Monodora myristica (Dunal, 1831) and Conyza sumatrensis (Retzius, 1742 - 1821) Extracts: Studies on Two Dipterous Insect Pests; Anopheles gambiae(Giles, 1902) and Culex quinquefasciatus (Say, 1823). Brizillian Journal of Biological Sciences 5: 347-358.

22. Ileke KD, Adesina FP (2018) Bioefficacy of Larvicidal and Pupicidal Properties of Clerodendrum capitatum and Bridelia machrantha Leaves Extracts against Malaria Vector, Anopheles gambiae Giles [Diptera: Culicidae]. Journal of Biology and Medicine 2: 7-11.

23. Odugbemi TT (2006) Outline and Pictures of Medicinal Plants from Nigeria. University of Lagos Press, Lagos, Nigeria, 283.

24. Fu PP, Yang YC, Xia Q, Chou MW, Cui YY, et al. (2002) Pyrrolizidine alkaloids-tumorigenic components in Chinese herbal medicines and dietary supplements. Journal of Food and Drug Analysis 10: 198-211.

25. Rajmohan D, Logankumar K (2011) Studies on the insecticidal properties of Chromolaena odorata (Asteraceae) against the life cycle of the mosquito, Aedes aegypti (Diptera: culicidae). Journal of Research in Biology 4: 253-257.

26. Mandal G, Joshi SP (2014) Invasion establishment and habitat suitability of Chromolaena odorata( $(\mathrm{L})$ king and Robinson overtime and space in the western Himalayan forests of India. Journal of Asia Pacific Biodiversity 7: 391-400.

27. Food and Agriculture Oganisation (FAO) (2001). Vernonia amygdalina.

28. Ologunde MO, Ayorinde FO, Shepard RL, Afolabi OA, Oke OL (1992) Sterols of seed oils of Vernonia galamensis, Amaranthus cruentus, Amaranthus caudatus, Amaranthus hybridus and Amaranthus hypochondriacus growth in the humid tropics. Journal of Food Agriculture 58: 221-225.

29. Bonsi MLK, Osuji PO, Tuah AK, Umunna NN (1995) Vernonia amygdalina as a supplement to teff straw (Eragrosistef) fed to Ethiopian Menz sheep. Agroforest Syst 31: 229-241.

30. Gillies MT, De Meillon B (1968) The Anophelinae of Africa South of the Sahara (Ethiopian Zoogeographical Region). $2^{\text {nd }}$. South African Institute for Medical Research, Johannesburg, 1-343.

31. Afolabi OJ, Simon-Oke I, Oluwadoyinsolami EO, Oniya MO (2018) Adulticidal and repellent activities of some botanical oils against malaria mosquito: Anopheles gambiae (Diptera: Culicidae). Beni-Suef University Journal of Basic and Applied Sciences 7: 135-138.

32. Udo IO (2011) Potentials of Zanthoxylum xanthoxyloides (LAM) for the control of stored product insect pests. Journal Stored Products and Postharvest Research 2: 40-44.

33. World Health Organization (WHO) (2006) Guidelines for testing mosquito adulticides for indoor residual spraying and treatment of mosquito nets. WHO Bulletin 3: 27-39.

34. Abbott WS (1925) A method of computing the effectiveness of an insecticide. Journal of Economic Entomology 18: 265267. 
35. Adedire CO, Lajide $L$ (2008) Ability of extract of ten tropical plant species to protect maize grains against infestation by the maize weevil Sitophilus zeamais during storage. Nigerian Journal of Experimental Biology 4: 175-179.

36. Musa AK, Oyerinde AA, Owolabi FO (2009) Evaluation of the Efficacy of Mixed Leaf Powders of Vernonia amygdalina $\mathrm{L}$ and Ocimum gratissimum against Callosobruchus maculatus. Academic Journal of Entomology 2: 85-87.

37. Moses O, Dorathy O (2011) Pesticidal Effect of Some Plant Materials for the Control of Weevils (Callosobruchus maculatus) in Some Varierties of Cowpea during Storage in Makurdi, Southern Guinea Agro-ecological zone of Nigeria. Entomological Society of Nigeria, 42nd Annual Conference Ibadan Book of Abstracts, 20.

38. Ahiati JA (2013) Study of the insecticidal Effects of Chromolaena Odorata Oil extracts on the Larvae and Adults of Mosquitoes (Family Culicidae).

39. Akunne CE, Ononye BU, Mogbo TC (2013) Evaluation of the Efficacy of Mixed Leaf Powders of Vernonia amygdalina (L.) and Azadirachta indica (A. Juss) Against Callosobruchu maculatus (F.) (Coleoptera: Bruchidae). Advances in Bioscience and Bioengineering 1: 86-95.

40. Jagruti HS, Hemanth Kumar, Godinho MHS, Ashwani K (2014) Larvicidal activity of methanolic leaf extracts of plant, Chromo laenaodorata L. (Asteraceae) against vector mosquitoes. International Journal of Mosquito Research 1: 33-38.

41. Udebuani AC, Abara PC, Obasi KO, Okuh SU (2015) Studies on the insecticidal properties of Chromolaena odorata (Asteraceae) against adult stage of Periplaneta Americana. Journal of Entomology and Zoology Studies 3: 318-321.

42. Ileke KD (2015) Entomotoxicant potential of Bitter leaf, Vernonia amygdalina powder in the control of Cowpea Bruchid, Callosobruchus maculatus (Coleoptera: Chrysomelidae) in- festing stored cowpea seeds. Octa Journal of Environmental Research 3: 226-234.

43. Bhattacharya K, Chandra G (2014) Phagodeterrence, larvicidal and oviposition deterrence activity of Tragia involucrata L. (Euphorbiaceae) root extractives against vector of lymphatic filariasis Culex quinquefasciatus(Diptera: Culicidae). Asian Pacific Journal of Tropical Diseases 4: S226-S232.

44. Pascual ME, Slowing K, Carretero E, Sánchez Mata D, Villar A (2001) Lippia: Traditional Uses, Chemistry and Pharmacology: A Review. J Ethnopharmacol 76: 201-214.

45. Man NC (2013) Phytochemical analysis of leaves of Chromolaena odorata. International Journal of Scientific and Research Publication 3: 1-2.

46. Acero LH (2014) Dried Siam weed (Chromolaena odorata) as rice weevils (Sitophilus oryza) eradicant. International Journal of Chemical Engineering and Applications 5: 363366 .

47. Ileke KD (2014) Insecticidal and toxicological studies on Alstoniaboonei De Wild used as cowpea protectant against Collosobruchus maculatus (Fab). Federal University of Technology, Akure, Nigeria, 269.

48. Kelm MA, Nair MG (1998) Mosquitocidal compounds and triglyceride, 1,3- Dilinoleneoyl -2- Palmitin from Ocimum sanctum. Journal of Agriculture Food and Chemistry 46: 3092-3094.

49. Barbosa P, Gross P, Provan GJ, Stermiz FR (1990) Allelochemicals in foliage of unfavored tree hoss of the gypsy moth Lymantria dispar L. seasonal variation of saponins in Ilex opacea and identification of saponin aglycones. Journal of Chemistry and Ecology 16: 1731-1738.

50. Geyter De E, Swevers L, Soin T, Geelen D, Smagghe G (2012) Saponins do not affect the ecdysteroid receptor complex but cause membrane permeation in insect culture cell lines. J Insect Physiol 58: 18-23. 